\title{
PENGARUH PEMBERIAN DAUN SAMBUNG NYAWATERHADAP PENURUNAN TEKANAN DARAH PADA PENDERITA HIPERTENSI USIA 46-55 TAHUN DI DESA KUAPAN WILAYAH KERJA PUSKESMAS TAMBANG
}

\author{
Ridha Hidayat \\ Dosen Prodi Sarjana Keperawatan FIK Universitas Pahlawan Tuanku Tambusai
}

\begin{abstract}
ABSTRAK
Hipertensi dapat menyerang hampir semua golongan masyarakat di seluruh dunia.Jumlah penderita hipertensi terus bertambah dari tahun ke tahun.Data dari WHO (2010) menyatakan bahwa hipertensi merupakan penyakit nomor sebelas penyebab kematian tertinggi di dunia yaitu sebanyak 1.153.308 jiwa. Tujuan penelitian ini adalah untuk pengaruh pemberian daun sambung nyawaterhadap penurunan tekanan darah pada penderita hipertensi usia 45-59 tahun di desa kuapan wilayah kerja puskesmas tambang tahun 2016. Hipertensi adalah suatu keadaan dimana seseorang mengalami peningkatan tekanan darah diatas normal yang mengakibatkan peningkatan angka morbiditas dan angka kematian.Jenis penelitian ini menggunakan metode eksperimen semu (quasi exsperimen) dengan rancangan non- equivalent pretest-posttest.Populasi dalam penelitian ini adalah seluruh masyarakat yang menderita hipertensi di Desa Kuapan sebanyak 136 orang dengan jumlah sampel 20 orang, adapun teknik pengambilan sampel menggunakan teknik purposive sampling. Hasil penelitian didapatkan rata- rata tekanan darah sebelum diberikan daun sambung nyawasistolik 150,67 mmhg, sedangkan rata-rata tekanan darah sistolik setelah diberikan daun sambung nyawa136,33 mmhg dan rata-rata tekanan darah sesudah diberikan daun sambung nyawadiastolik 97,67 mmhg, sedangkan rata-rata tekanan darah diastolik setelah diberikan daun sambung nyawa87,67 mmhg. Diharapkan pada responden untuk dapat mengontrol tekanan darah pada puskesmas secara rutin dan mengkonsumsi makanan yang tinggi serat serta mengupayakan mengkonsumsi obat herbal sebagai pengobatan hipertensi untuk jangka panjang sesuai dengan dosis toleransi tubuh.
\end{abstract}

Daftar Bacaan : 29 ( 2008 - 2015)

Kata Kunci : Hipertensi, Daun sambung nyawa

\section{PENDAHULUAN}

\section{A. Latar Belakang}

Indonesia Cinta Sehat merupakan cermin sikap dan perilaku segenap bangsa
Indonesia yang mencintai kesehatan dirinya, keluarganya, dan lingkungannya. Hal itu adalah kunci keberhasilan bagi terwujudnya masyarakat sehat yang mandiri.Salah satu program 
jaminan kesehatan semesta pada tahun 2020, seluruh penduduk Indonesia mempunyai jaminan kesehatan.Ini berarti bahwa masyarakat Indonesia diharapkan dapat memperoleh pelayanan kesehatan yang komprehensif dan bermutu dengan semakin meningkatnya kesejahteraan masyarakat di negara berkembang tingkat kejadian berbagai penyakit degeneratif semakin meningkat salah satunya Hipertensi (Profil Kemenkes RI, 2012).

Hipertensi atau lebih dikenal dengan penyakit tekanan darah tinggi adalah suatu keadaan dimana seseorang mengalami peningkatan tekanan darah diatas normal yang ditunjukkan oleh angka sistolik (bagian atas) dan diastolik (bagian bawah) pada pemeriksaan tekanan darah menggunakan alat pengukur tekanan darah baik yang berupa cuff air raksa (sphygmomanometer) ataupun alat digital lainnya (Shadine, 2010).

Data di Provinsi Riau periode 2013 - 2014 tercatat masih tinggi, yaitu mencapai 24\%. Padahal tahun 2010 - 2011 dapat diturunkan 7,9\%, tapi justru terjadi peningkatan tahun 2012 menjadi $11,4 \%$ dan tahun 2013 terus meningkat menjadi 24\%. Hal ini menyebabkan semakin meningkatnya angka morbiditas dan mortalitas setiap tahun akibat penyakit hipertensi terutama jika penyakit ini tidak dapat dikontrol secara teratur (Profil Kesehatan Riau, 2012).
Data penderita hipertensi di Kabupaten Kampartahun 2015 penderita hipertensi diseluruh wilayah Kabupaten Kampar Puskesmas Tambang berada pada urutan pertama kasus hipertensi yaitu 4.504 (20,0\%). Urutan kedua kasus hipertensi yaitu Puskesmas Kampar dengan kasus hipertensi $2.286(10,1 \%)$ dan urutan ke tiga Puskesmas Kampar Timur dengan kasus hipertensi $\quad 1.740$ $(7,72 \%)$.Sedangkan untuk data kejadian hipertensi diwilayah kerja Puskesmas Tambang tahun 2015 berada di Desa Kuapan 136orang dengan golongan umur yaitu pada umur 45-59 tahun.Obat-obat hipertensi sekarang ini masih belum sepenuhnya memberikan jawaban atau solusi untuk para penderita. Selain harganya yang cukup mahal banyak efek samping yang ditimbulkan pada pemakaian obat- obatan ini. Hal inilah yang menyebabkan masyarakat mulai mencari alternatif pengobatan yang lain salah satunya melalui terapi herbal (Utami, 2013).

Terapi herbal adalah pengobatan dengan menggunakan tanaman yang berkhasiat obat. Indonesia merupakan negara yang sangat kaya akan ragam floranya. Keadaan ini sangat menguntungkan bagi masyarakat kita dalam melakukan terapi herbal. Terapi dengan menggunakan tanaman obat ini sangat populer pada masyarakat kita dewasa ini, karena efek 
sampingnya sedikit, murah dan mudah didapat. Salah satu tanaman obat yang dapat digunakan sebagai obat herbal hipertensi adalah tanaman sambung nyawa (Samsudin, 2014).

Berdasarkan hasil survei awal yang dilakukan diPuskesmas Tambang tahun 2016 dari 15 orang penderita hipertensi, 2 orang mengatakan pernah mencoba daun sambung nyawa sebagai obat herbalpenurun tekanan darah, 3 orang mengatakan bahwa mereka hanya mengetahui tanaman daun sambung nyawa, sedangkan 10 orang lainnya mengatakan bahwa mereka belum mengetahui tentang daun sambung nyawa, cara mengkonsumsi serta manfaat dari tanaman sambung nyawa tersebut. Selama ini masyarakat penderita hipertensi hanya mengkonsumsi obat-obat kimia untuk mengatasi hipertensi mereka yang tinggi tanpa memikirkan efek samping dari obat kimia tersebut.

Berdasarkan latar masalah dan fenomena yang terjadi diatas, maka peneliti termotivasi untuk melakukan penelitian tentang "Pengaruh Pemberian Daun Sambung Nyawa (Gynura Procumbens) Terhadap Penurunan Tekanan Darah pada Penderita Hipertensi di Desa Kuapan Wilayah Kerja Puskesmas Tambang Tahun 2016".

\section{B. Rumusan Masalah}

Berdasarkan uraian masalah pada latar belakang diatas, maka dapat dirumuskan masalah penelitian sebagai berikut :" Apakah ada pengaruh pemberian daun sambung nyawa (gynura procumbens) terhadap penurunan tekanan darah pada penderita hipertensi di desa Kuapan wilayah kerja Puskesmas Tambang tahun 2016?"

\section{Tujuan penelitian}

Tujuan umum : untuk menganalisis

pengaruhpemberian daun sambung nyawa (gynura procumbens) terhadap penurunan tekanan darah pada penderita hipertensi di desa Kuapan wilayah kerja Puskesmas Tambang

\section{Manfaat Penelitian}

1. Aspek Teoritis Penelitian ini diharapkan dapat memberikan suatu masukan untuk teori serta dapat dijadikan sebagai sumber referensi dan bahan bacaan dalam meningkatkan

pengetahuan mahasiswa khususnya jurusan keperawatan tentang pengaruh konsumsi daun sambung nyawa terhadap penurunan tekanan darah.Hasil penelitian ini dapat digunakan untuk menyusun hipotesis baru 
dalam merancang penelitian selanjutnya.

2. Aspek Praktis

Hasil penelitian ini diharapkan dapat menambah wawasan dan pengetahuan responden khususnya penderita hipertensi tentang manfaat mengkonsumsi daun sambung nyawa secara teratur untuk menurunkan tekanan darah.

\section{TINJAUAN TEORITIS}

\section{Daun Sambung Nyawa}

\section{a. DefinisiDaun Nyawa}

Sambung Tanaman Sambung Nyawa (Gynura procumbens) atau yang biasa disebut ngokilo (bahasa jawa). Berasal dari daerah Afrika yang beriklim tropis, dan menyebar ke Srilangka, Sumatera dan Jawa. Tumbuh liar di pekarangan, ladang, semak, selokan dan tempat-tempat lain. Tumbuh dengan baik sampai ketinggian $500 \mathrm{~m}$ di atas permukaan laut.

\begin{tabular}{lr}
\multicolumn{2}{c}{ Sambung nyawa } \\
(Gynura procumbens) \\
merupakan nama & tanaman \\
berkhasiat obat. & Khasiat \\
daun yang juga & disebut \\
sebagai daun ngokilo & nat \\
terhadap diabetes & sudah \\
diuji di sejumlah penelitian \\
di luar negeri. Berikut cara \\
pemanfaatn daun sambung \\
nyawa untuk pengobatan \\
berbagai penyakit seperti
\end{tabular}

diabetes melitus, darah tinggi, dan lainnya yang diperoleh dari berbagai sumber(Sudarjo, 2014).

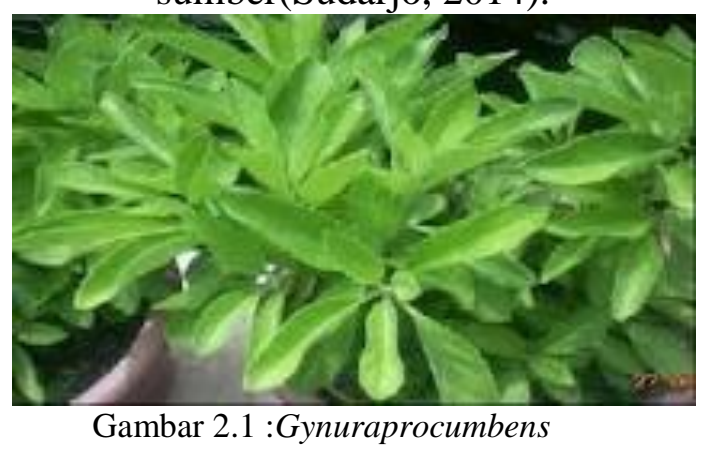

\section{b. Kandungan Kimia}

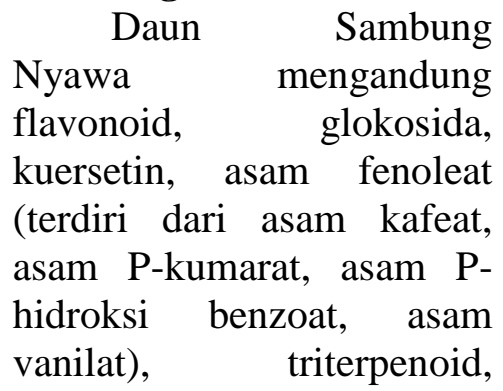
saponi, steroid, dan minyak atsiri. Kandungan zat aktif yang dominan dari daun sambung nyawa adalah flavonoid yang bekerja denganmeningkatkan

konsentrasi serum NO (Nitrite Oxide). NO merupakan molekul kecil yang berfungsi sebagai vasodilator dan menyebabkan tekanan darah menurun.

c. Manfaat

Daun sambung nyawa (Gynura procumbens) berkhasiat sebagai diuretik, antipiretik, hipotensi, hipoglikemik (menurunkan kadar gula darah), mencegah dan meluruhkan batu ginjal dan batu 
masyarakat dan 20 orang yang memenuhi kriteria inklusi. dengan metode purposive sampling atau judgement sampling,

\section{Prosedur Pengumpulan Data}

Untuk keperluan analisa data, peneliti memerlukan sejumlah data pendukung yang berasal dari dalam dan luar lapangan. Untuk itu peneliti menggunakan dua macam cara pengumpulan data, yaitu sebagai berikut :

\section{Data Primer \\ Data}

dikumpulkan

sendiri oleh peneliti dengan

\begin{tabular}{cll}
\hline No & Variabel & \multicolumn{1}{c}{$\begin{array}{c}\text { Defenisi } \\
\text { Operasional }\end{array}$} \\
\hline $\mathbf{1}$ & Independen & \\
\hline & Pengaruh & Pemberian daun \\
pemberian & sambung nyawa \\
& komsumsi & yang dikonsumsi 7 \\
& daun & lembar (600 mg) \\
& sambung & setiap hari sebagai \\
& nyawa & lalapan selama 6 hari \\
& & di siang hari pada \\
& & masyarakat di Desa \\
& & Kuapan
\end{tabular}

\begin{abstract}
melakukan anamnesa
berdasarkan keluhan yang dirasakan penderita, serta melakukan pengukuran tekanan darah menggunakan sphygmomanometer dan tujuannya disesuaikan dengan keperluan peneliti.
\end{abstract}

\section{Defenisi Operasional}

Defenisi operasional adalah uraian tentang batasan variable yang di maksud atau tentang apa yang diukur oleh variable yang bersangkutan (Notoatmodjo, 2010).

Tabel 3.1 : Defenisi Operasional 
mendeskripsikan karateristik setiap variabel penelitian (Notoatmodjo, 2010). Dalam penelitian ini penulis menganalisa data secara univariat yaitu analisis yang hanya meliputi satu variabel yang disajikan dalam bentuk perhitungan mean, standar deviasi, nilai minimal dan maksimal hasil yang akan digunakan sebagai tolak ukur dalam pembahasan dan kesimpulan dengan menggunakan rumus :

$$
\mathrm{P}=\frac{f}{N} \times 100 \%
$$

$\mathrm{P}=$ Persentase

$\mathrm{F}=$ Frekuensi

$\mathrm{N}=$ Jumlah seluruh observasi(Sudyono, 2010)

\section{2) Analisa Bivariat}

Analisa bivariat yang
dilakukan terhadap dua
variabel yang di duga
berhubungan atau berkorelasi (Notoatmodjo, 2010). Dalam penelitian ini analisa bivariat digunakan untuk menganalisa perbedaan tekanan darah lansia penderita hipertensi sebelum dan setelah diberikan daun sambung nyawa. Sehingga dalam analisis ini dapat digunakan uji statistik uji $\mathrm{T}$ test atau Paired T-test yaitu uji dua mean dependen. Uji dua mean dependen digunakan untuk menguji perbedaan mean antara dua kelompok data yang dependen (Kholilatul, 2009).

Dasar pengambilan keputusan yaitu melihat hasil analisa pada $P$ value. jika $p$ value $\leq 0,05$ maka artinya ada konsumsi daun sambung nyawa terhadap penurunan tekanan darah pada penderita hipertensi di Desa Kuapan dan sebaliknya, jika $p$ value $\geq 0,05$ maka artinya tidak ada pengaruh terapi diet daun sambung nyawa terhadap penurunan tekanan darah pada penderita hipertensi di Desa Kuapan wilayah kerja Puskesmas Tambang.

\section{HASIL PENELITIAN}

Penelitian ini dilakukan pada tanggal 01 sampai 14 Mei 2016 di Desa Kuapan wilayah kerja Puskesmas Tambang dengan judul “ Pengaruh daun sambung nyawa terhadap penurunan tekanan darah pada usia 45-59 tahun di Desa Kuapan ".Analisa data yang ditampilkan dalam penelitian ini berupa analisa univariat dan bivariat yaitu sebagai berikut :

\section{A. Analilsa Univariat}

Analisa

univariat dilakukan untuk melihat distribusi karakteristik responden seperti umur, jenis kelamin, pendidikan dan pekerjaan. Adapun analisa univariat dapat dilihat pada tabel berikut:

\section{Tabel 4.1Distribusi Frekuensi Jenis Kelamin, Pendidikan dan Pekerjaan Responden}

\begin{tabular}{lcc}
\hline Variabel & Frekuensi & $\begin{array}{c}\text { Persentase } \\
(\boldsymbol{\%})\end{array}$ \\
Umur & & \\
45 Tahun & 3 & 15 \\
\hline
\end{tabular}




\begin{tabular}{lcc} 
46 Tahun & 5 & 25 \\
47 Tahun & $\mathbf{9}$ & $\mathbf{4 5}$ \\
48 Tahun & 2 & 10 \\
49 Tahun & 1 & 5 \\
& & \\
\hline Jumlah & $\mathbf{2 0}$ & $\mathbf{1 0 0 \%}$ \\
\hline Jenis Kelamin & & \\
Perempuan & 20 & 100 \\
& & \\
\hline Jumlah & $\mathbf{2 0}$ & $\mathbf{1 0 0 \%}$ \\
\hline Pendidikan & & \\
SD & & \\
SMP & 5 & 25 \\
SMA & $\mathbf{8}$ & $\mathbf{4 0}$ \\
Perguruan & 5 & 25 \\
Tinggi & 2 & 10 \\
\hline \multicolumn{1}{c}{ Jumlah } & $\mathbf{2 0}$ & $\mathbf{1 0 0}$ \\
\hline Pekerjaan & & $\mathbf{4 5}$ \\
IRT & $\mathbf{9}$ & 30 \\
Petani & 6 & 25 \\
PNS & 5 & $\mathbf{1 0 0}$ \\
$\quad$ & & \\
\hline Jumlah & & \\
\hline
\end{tabular}

Seperti disajikan pada tabel 4.1 dapat diketahui bahwa sebagian besar responden berusia 47 tahun (45\%), sebagian besar responden berjenis kelamin perempuan (100\%), sebagian besar tingkat pendidikan SMP (46,7\%), serta pekerjaan responden sebagai besar IRT (60\%).

Tabel 4.2 Distribusi Frekuensi Tekanan Darah Sistolik dan Diastolik Sebelum

Mengkonsumsi daun sambung nyawa pada Penderita Hipertensi

\begin{tabular}{lcccc}
\hline Variabel & Mean & $\begin{array}{c}\text { Min- } \\
\text { Maks }\end{array}$ & SD & $\begin{array}{c}\text { C1 } \\
\mathbf{9 5 \%}\end{array}$ \\
\hline $\begin{array}{l}\text { Tekanan } \\
\text { Darah } \\
\text { Sistolik }\end{array}$ & 150,50 & $140-160$ & 5,826 & 147,77 \\
\hline
\end{tabular}

\begin{tabular}{lllll}
\hline Sebelum & & & & \\
\hline Tekanan & 97,00 & $85-105$ & 5,477 & 94,44 \\
Darah & & & & \\
Diastolik & & & & \\
Sebelum & & & & \\
\hline
\end{tabular}

Berdasarkan tabel 4.2 menunjukkan bahwa sebelum mengkonsumsi daun sambung nyawa rata-rata tekanan darah sistolik 150,50 mmhg, sedangkan rerata tekanan darah diastolik 97,00 mmhg.

\section{Tabel 4.3 Distribusi Frekuensi Tekanan Darah Sesudah mengkonsumsi daun sambung nyawa Pada Penderita Hipertensi}

\begin{tabular}{lclcc}
\hline Variabel & Mean & $\begin{array}{c}\text { Min- } \\
\text { Maks }\end{array}$ & SD & $\begin{array}{c}\text { C1 } \\
\mathbf{9 5 \%}\end{array}$ \\
\hline $\begin{array}{l}\text { Tekanan } \\
\text { Darah }\end{array}$ & 131,25 & $120-$ & 7,048 & 127,9 \\
$\begin{array}{l}\text { Sistolik } \\
\text { Setelah }\end{array}$ & & 145 & & 5 \\
\hline $\begin{array}{l}\text { Tekanan } \\
\text { Darah }\end{array}$ & 87,25 & $75-95$ & 5,730 & 84,57 \\
$\begin{array}{l}\text { Diastolik } \\
\text { Setelah }\end{array}$ & & & & \\
\hline
\end{tabular}

Berdasarkan tabel 4.3 menunjukkan bahwa sesudah daun sambung nyawa, rerata tekanan darah sistolik 131,25 mmhg, sedangkan rerata tekanan darah diastolik 87,25 mmhg.

\section{B. Analisa Bivariat}

Dalam penelitian ini, analisa bivariat digunakan untuk menganalisa perbedaan tekanan darah responden sebelum dan sesudah konsumsi daun sambung nyawa dengan menggunakan uji Paired $t$ Test. Adapun syarat uji ini adalah satu 
sampel (setiap elemen ada 2 pengamatan), data kuantitatif (interval-rasio) dan berasal dari populasi yang berdistribusi normal (Purnomo, 2006). Perbedaan tekanan darah responden sebelum dan sesudah konsumsi daun sambung nyawapeneliti sajikan dalam bentuk tabel sebagai berikut

Tabel 4.4 Perbedaan Tekanan Darah Sebelum dan Sesudah Mengkonsumsi daun sambung nyawa Penderita Hipertensi

\begin{tabular}{|c|c|c|c|}
\hline Variabel & $\begin{array}{c}\text { Selisih } \\
\text { Mean }\end{array}$ & $\begin{array}{c}\text { Std. } \\
\text { Deviation }\end{array}$ & $\begin{array}{c}\text { P } \\
\text { value }\end{array}$ \\
\hline $\begin{array}{c}\text { Sitolik } \\
\text { sebelum } \\
\text { sesudah }\end{array}$ & 19,250 & 4,667 &, 0001 \\
\hline $\begin{array}{c}\text { Diastolik } \\
\text { sebelum } \\
\text { sesudah }\end{array}$ & 9,750 & 4,128 &, 0001 \\
\hline
\end{tabular}

Berdasarkan tabel 4.4 dapat dilihat bahwa secara statistik terdapat perbedaan yang signifikan antara tekanan darah responden sebelum dan sesudah minum daun sambung nyawa dengan selisih mean tekanan darah sisolik sebesar 19,250 dan diastolik sebesar 9,750. Berdasarkan uji Shapiro-Wilk diperoleh nilai > 0,05 yaitu nilai sistol sebelum diberikan konsumsi daun sambung nyawa adalah 0,064 , sistol sesudah diberikan konsumsi daun sambung nyawa adalah 0,20 , diastol sebelum diberikan konsumsi daun sambung nyawa adalah 0,085, diastol sesudah diberikan konsumsi daun sambung nyawa adalah 0,89 , maka dapat disimpulkan bahwa data berdistribusi normal. Hal ini dibuktikan dengan $\mathrm{p}$ value 0,0001 dengan demikian terdapat pengaruh pemberian daun sambung nyawa terhadap penurunan tekanan darah.

\section{PEMBAHASAN}

Berdasarkan hasil penelitan menunjukkan bahwa sebelum minum daun sambung nyawa rata-rata tekanan darah sistolik 160,67 mmhg, sedangkan rata-rata tekanan darah diastolik 97,67 mmhg. Sedangkan setelah diberikan konsumsi daun sambung nyawa rata-rata tekanan darah sistolik 136,33 mmhg, sedangkan rata - rata tekanan darah diastolik 87,67 mmhg. Hal ini terdapat perbedaan yang signifikan antara tekanan darah responden sebelum dan sesudah daun sambung nyawa dengan selisih mean tekanan darah sistolik sebesar 14,333 dan diastolik sebesar 10,00. Hal ini dibuktikan dengan $\mathrm{p}$ value 0,0001 dengan demikian terdapat pengaruh konsumsi daun sambung nyawa terhadap penurunan tekanan darah.

Hasil penelitian ini sesuai dengan teori Setiawan (2009) yang mengatakan bahwa tanaman sambung nyawa mempunyai kandungan seperti minyak asiri, saponin dan flavonoida. Selain itu sambung nyawa memiliki sifat dingin, netral, antitoktik, bersifat hipotensif (menurunkan tekanan darah), anti kanker dananti radang. 
nyawa antara kelompok kasus dengan kelompok kontrol dan dapat dijadikan bahan acuan dalam menyusun hipotesis baru dalam penelitian berikutnya

\section{DAFTAR PUSTAKA}

Dinkes Kabupaten Kampar. (2015). Penyakit Hipertensi di Kabupaten Kampar.

Depkes RI. (2012). Kejadian Hipertensi dI Indonesia.Diperoleh tanggal 02 Januari 2016 dari http://kejadian hipertensi di Indonesia.undip.ac.id

Hidayat,

A.A.

(2012). RisetKeperawatan dan Teknik Penulisan Ilmiah.Jakarta : Salemba Medika

Hidayat, A.A. (2012). Riset Keperawatan dan Teknik Penulisan Ilmiah.Jakarta : Salemba Medika

Hendra. (2012).

Tingkat Pengetahuan Penderita Hipertensi di Puskesmas Ngawen I Kabupaten Gunung Kidul Provinsi D.I.Y. Universitas Muhammadiyah Surakarta

Indrayani.(2009). Asuhan Keperawatan Pasien denga Hipertensi.Jakarta : Penebar Plus

Iskandar. (2010). Analisis Data Penelitian. Jakarta: Penerbit Andi.
Kasjono \& Yasril.(2009). Teknik Sampling Untuk Penelitian Kesehatan.Yogyakarta : Graha Ilmu

Kemenkes RI. (2012). Mewujudkan Indonesia Cinta Sehat 2020. Diperoleh tanggal 15 Januari 2016 dari http://id.adobe readr/pdf/kemenkes $\mathrm{RI} /$ indonesia-cinta-sehat-2020

Nurlaela. (2009). Mengenal usia lanjut dan perawatannya. Jakarta: Buana Pustaka Puskesmas Tambang (2015). Penyakit hipertensi di Puskesmas Tambang.

Nurachmah.

(2009).

Penatalaksanaan penyakit dengan Hipertensi. Diperoleh pada tanggal 10 januari 2016 dari Http:// nurachmah.blogspot.com

Notoatmodjo, S. (2005).Metodologi Penelitian Kesehatan. Jakarta : Rineka Cipta

Notoatmodjo, S. (2010).Metodologi Penelitian Kesehatan. Jakarta: Rineka Cipta

Nursalam.(2008). Konsep \&
Penerapan Metodologi
Penelitian Ilmu Keperawatn
Pedoman Skripsi, Tesis dan
Instrumen Penelitian
Keperawatan.Jakarta :
Salemba Medika
Palmer.
(2007. Hipertensi.Jakarta :
PT.Gramedia Pustaka
Utama


Putra. (2013). Efek penurunan tekanan darah dan gula darah dari fraksi air daun sambung nyawa pada tikus hipertensi dan diabetes. Diperoleh tanggal 01 Maret 2016-04-16.

Rahmad. (2013). Analisa penatalaksanaan penyakit hipertensi Di RS Dr. Soetomo Surabaya.Skripsi : Malang. Fakultas IlmuKesehatan Universitas Brawijaya

Shadine. (2010). Tekanan Darah Tinggi. Jakarta: Salemba Medika

Susilo, dkk.(2012). Faktor-faktor yang Berhubungan dengan Hipertensi Pada Lansia di Desa Sigaol Simbolon Kabupaten Samosir Tahun 2012.Skripsi Mahasiswa FKM USU

Samsudin. (2014). Terapi herbal untuk masyarakat dengan penyakit hipertensi. Yogyakarta :Erlangga

Setiawan. (2009). (2009). Daun Sambung Nyawa untuk Penurunantakanan DarahPada Penderita hipertensi. Jakarta: Salemba Medika

Sudarjo. (2014). Daun sambung nyawa sebagai terapi herbal hipertensi.

http://www.depkes.go.id/do wnload.publikasi ditjen (diakses padatanggal 12 Januari 2016

Sudarmoko.(2010). Tata Laksana
Depertemen Kardiologi, Rs Premier Jatinegara

Sani. (2008). Menu Sehat Penakluk Hipertensi.Jakarta

Demedia Pustaka

Setiawan. (2009). Tanaman herbal sambung nyawa .

Yogyakarta:Salemba

Medika

Sudyono. (2010). Metodologi

Penelitian Kesehatan. Edisi

3. Yogyakarta:Mitra

Cendekia Press.

Utami.(2013). Terapi Herbal Untuk Diabetes Mellitus Tipe

II.Jakarta : Agro Media

Pustaka

Winarto. (2003). Daun Sambung Nyawa Untuk Kesehatan. Jakarta : Erlangga

Zamzami. (2014). Pengaruh daun sambung nyawa terhadap penurunan tekanan darah pada penderita hipertensi di Puskesmas Air Dingin Kecamatan Kota Tangah Kota Padang. Diperoleh tanggal 13 Mei 2016 